\title{
EDUKASI PEMBANGKIT LISTRIK TENAGA SURYA BUATAN "INTEGRATED SOLAR PANEL-SENSITIZED SOLAR CELL" BAGI MADRASAH ALIYAH NU LEKOK DAN MASYARAKAT DUSUN SEMONGKRONG, PASINAN, PASURUAN
}

\author{
Mahendra Satria Hadiningrat ${ }^{1}$, Reza Ardiansyah ${ }^{2}$, Eggi Aunur Rofiq ${ }^{3}$ \\ Pendidikan Fisika, FIP, Institut Teknologi dan Sains Nahdlatul Ulama Pasuruan ${ }^{1,3}$ \\ Pendidikan Biologi, FIP, Institut Teknologi dan Sains Nahdlatul Ulama Pasuruan ${ }^{2}$ \\ Jl. Raya Warung Dowo, Pohjentrek, Pasuruan \\ mahendra@itsnupasuruan.ac.id
}

\begin{abstract}
ABSTRAK
Telah dilakukan program kegiatan pengabdian masyarakat, mengkhususkan dengan merancang dan membuat panel surya buatan berbiaya rendah untuk MA NU Lekok dan Masyarakat dusun Semongkrong Barat-Tengah, Pasinan, Pasuruan dan sekitarnya. Tujuan kegiatan yang kami lakukan adalah memberi edukasi dan pengembangan diri kepada peserta didik khususnya di sekolah MA NU Lekok dan memberikan bantuan alat panel surya untuk 10 titik penerangan jalan di Dusun Semongkrong Barat-Tengah. Setelah diadakannya pembinaan dan pelatihan berkala, diharapkan peserta didik dan masyarakat dusun sudah memiliki kompetensi untuk mengembangkan panel surya secara mandiri dan dapat diproduksi secara massal/ diperbanyak. Adanya alternatif panel surya yang kami kembangkan melalui penelitian berkelanjutan ini, dengan daya kecil dan mampu menghasilkan listrik hingga 100 Watt (untuk kapasitas penerangan/lampu jalan) dapat beroperasi dengan baik dan layak untuk digunakan. Melalui kebermanfaatan alat kami, khususnya di area akses jalan Dusun Semongkrong dapat meminimalisir terjadinya tindak kejahatan yang merajalela. Kedepan dan untuk kelanjutan secara teknis, kami akan mengontrol alat dengan 2-3 kali frekuensi kunjungan per bulan untuk memastikan alat panel surya tetap dalam kondisi baik.
\end{abstract}

Kata kunci: Panel Surya; Buck Converter; Integrated Circuit

\begin{abstract}
A programme has been carried out, specializing in designing and making low-cost artificial solar panels for MA NU Lekok and the West-Central Semongkrong, Pasinan, Pasuruan and surrounding villages. The purpose of the activities we do is to provide education and selfdevelopment to learners, especially at the school MA NU Lekok and provide solar panel assistance for 10 lighting points in the West-Central Semongkrong. After holding coaching and regular training, it is expected that students and the village already have the competence to develop solar panels independently and can be mass produced/reproduced. The existence of alternative solar panels that we developed through ongoing research, with small power and capable of producing electricity up to 100 Watts (for lighting capacity/ street lights) can operate properly and suitable for use. Through the use of our tools, especially in access area of Semongkrong, the road can minimize the occurrence of crime. Forward and technical continuity, we will control the device with 2-3 times the frequency per month of visits to ensure the solar panel remains in good condition
\end{abstract}

Keyword: Solar Panel; Buck Converter; Integrated Circuit 


\section{PENDAHULUAN}

Lokasi yang menjadi sasaran kami dalam kegiatan ini berada di Dusun Semongkrong Barat-Tengah kelurahan Pasinan, kecamatan Lekok, kabupaten Pasuruan. Di dusun tersebut, masyarakatnya ada yang tinggal berjauhan dan tertinggal dalam sektor listrik, meskipun dekat dengan Pembangkit Listrik Tenaga Uap (PLTU). PLTU tidak mengalirkan listrik di beberapa wilayah sekitar area dusun. Pemukiman mereka terpisah-pisah antara kelompok satu dengan kelompok lainnya. Rumah mereka dipisahkan dengan ladang-ladang. Dengan kondisi geografis yang seperti itu tentu saja dibutuhkan kondisi jalan yang baik, salah satunya penerangan jalan saat malam hari.

Berdasarkan hasil wawancara yang kami lakukan kepada salah satu warga menyatakan bahwa sebagian besar di sepanjang jalan Dusun hampir tidak memiliki penerangan, sehingga banyak terjadi tindakan pembegalan (perampasan sepeda motor) dan para remaja yang sedang memanfaatkan situasi tersebut untuk menjalin hubungan yang tidak sewajarnya.

Dengan kondisi seperti itu, melalui kegiatan Pengabdian Masyarakat ini kami ingin membawa suatu perubahan, meng-edukasi siswa-siswi MA NU Lekok agar tetap semangat menjalani tugas sebagai peserta didik dengan membuat inovasi panel surya buatan secara mandiri sehingga dapat mampu memberikan tularan semangat untuk menerapkan halhal sederhana menjadi inovasi yang bermanfaat khususnya bagi masyarakat Lekok serta memberikan bantuan pengadaan Alat Panel Surya buatan agar dapat bermanfaat terutama akses transportasi/ jalan yang tadinya gelap menjadi terang sehingga warga sekitar yang melewati jalan terssebut merasa aman. Kami juga ingin memberikan edukasi kepada masyarakat tentang penggunaan panel surya sebagai sumber energi alternatif yang bisa digunakan selain dari PLN.(Tulandi, 2019)

\section{METODE}

Teknik dan cara pelaksanaan yang kami lakukan di kegiatan ini yaitu :

\section{Pendekatan (Interpersonal dan Intrapersonal)}

Kami melakukan pendekatan ke sekolah dan masyarakat dusun dengan tujuan agar mengetahui maksud dan tujuannya. Pertama, Kami akan menjelaskan bahwa kami akan meng-edukasi siswa-siswi MA NU Lekok membuat panel surya buatan secara mandiri serta mencoba membangun penerangan yang menggunakan tenaga matahari sebagai 
sumber energinya. Matahari yang biasanya hanya di buat untuk mengeringkan gabah maupun pakaian mereka, sekarang akan diubah menjadi energi listrik yang nanti pastinya akan sangat berguna sekali bagi mereka.

Serta, yang kedua, mengajak masyarakat Dusun Semongkrong terutama pemuda untuk suka rela membantu inovasi yang telah kami sampaikan ke siswa-siswi MA NU Lekok agar diperbanyak alat dan bahan untuk membuat panel buatan sehingga dapat bermanfaat untuk akses penerangan jalan, agar mereka juga dapat menerapkan teknologi pembangkit listrik tenaga surya yang kami lakukan ini.

\section{Pengaplikasian (Skala Prioritas)}

Setelah kami melakukan pendekatan, beberapa poin yang kami utamakan yaitu;

a) Edukasi pembuatan panel surya buatan di Laboratorium IPA MA NU Lekok, kemudian membuat Prototype dan Fabrikasinya

b) Penentuan 10 titik yang nantinya akan dipasang lampu penerangan jalan (menggunakan panel surya buatan), kemudian kami memasangnya bersama dengan masyarakat Dusun Semongkrong Barat-Tengah

c) Terakhir, kami akan menempelkan stiker di alat yang kami buat sebagai tanda kenang-kenangan

\section{Monitoring (Control Scale)}

Setelah kami memasang lampu penerangan yang telah kami buat di dusun Semongkrong Barat-Tengah dan Edukasi Pengembangan Panel surya di MA NU Lekok, kami akan mengontrol alat dengan frekuensi kunjungan 2-3 kali per-bulan dengan tujuan untuk memastikan alat yang kami buat tetap dalam kondisi baik.

\section{HASIL DAN PEMBAHASAN}

Sebelum mengarah pada hasil dan pembahasan, dijelaskan secara singkat Fabrikasi alat yang kami susun,

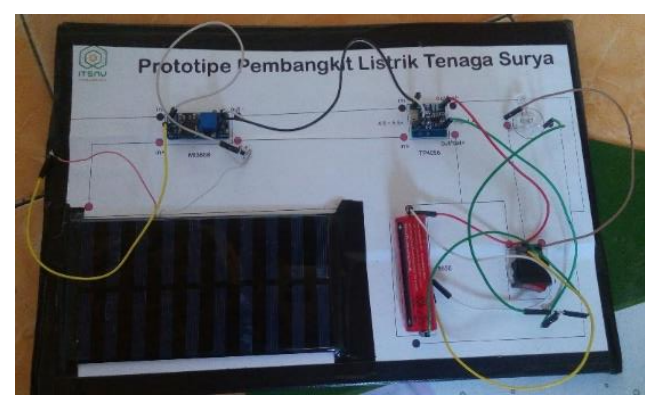

Gambar 1. Prototipe Pembangkit Listrik Tenaga Surya 
a) Panel Surya

Panel surya adalah alat yang berfungsi sebagai pengubah energi dari cahaya matahari menjadi listrik. Panel surya terbuat dari bahan semi konduktor (silikon) yang selanjutnya disusun menjadi sel-sel surya. Sel surya tersebut selanjutnya disusun seri dan paralel membentuk panel surya. Pada sel surya terdapat semi konduktor tipe $\mathrm{N}$ dan semikonduktor tipe P. Biasanya semikonduktor tipe $\mathrm{N}$ terletak diatas dan semikonduktor tipe P terletak di bawah. Semi konduktor tipe N ini mempunyai banyak elektron bebas (kelebihan elektron), sedangkan semikonduktor tipe P kekurangan elektron. Sehingga apabila ada energi Foton dari cahaya matahari yang mengenai sel surya, maka elektron dari semikonduktor tipe $\mathrm{N}$ akan mengalir/bergerak ke semikonduktor tipe $\mathrm{P}$. Hal itulah yang menyebabkan sel surya dapat menghasilkan arus listrik.

b) Buck Converter (step up)

Buck converter ini adalah alat yang berfungsi menyetabilkan tegangan dari sel surya menuju modul charger baterai sekaligus sebagai "batas" untuk menghambat arus kembali dari baterai menuju sel surya. Input tegangan yang dapat diterima adalah sebesar 2 - 24V dan arusnya maksimal 2A, sedangkan untuk outputnya maksimal sebesar 5 - 26V. Tegangan pada buck converter ini dapat diatur melalui mur/ sekrup yang ada padanya.

c) Modul Charger

Modul charger berfungsi untuk charger baterai 18650. Modul ini dapat mengisi baterai dengan arus maksimal 1A dan otomatis cut off ketika tegangan pada baterai mencapai 4,2V. Jadi baterai akan aman dari kelebihan muatan.

d) Baterai 18650

Baterai jenis ini adalah baterai yang dapat di isi ulang menggunakan listrik. Baterai ini mempunyai kapasitas $5800 \mathrm{mAh}$ dan mempunyai tegangan sebesar 3,7V.

e) LED (Light Emitting Diode)

LED adalah alat yang berfungsi sebagai beban (load) yang nantinya dapat menghasilkan cahaya. LED ini membutuhkan tegangan sebesar $3.2 \mathrm{~V}$ dan arus sebesar $30 \mathrm{~mA}$ agar menyala. 
Cara Kerja ;

1. Ketika sinar matahari mengenai sel surya, maka elektron yang terdapat pada semikonduktor tipe $\mathrm{N}$ akan mengalir ke semikonduktor tipe P. Aliran elektron itu menghasilkan listrik.

2. Listrik yang dihasilkan dari sel surya diteruskan ke buck converter agar tegangan dari sel surya ke modul charger menjadi stabil.

3. Saat modul charger menerima listrik dari buck converter, lalu akan diteruskan ke baterai sehingga baterai akan terisi dengan listrik. Indikator merah pada modul charger menandakan bahwa baterai belum penuh, dan indikator biru menandakan bahwa baterai telah penuh.

4. Listrik/ muatan yang tersimpan pada baterai akan digunakan untuk menyalakan lampu LED dan saklar sebagai pemutus arus apabila tidak digunakan

Hasil ;

1. Disaat memakai baterai lampu menyala dengan terang, tetapi untuk pengisian baterai cukup lama dikarenakan sel surya hanya bisa menghasilkan arus sebesar 200mA.

2. Ketika menggunakan sel surya (tanpa baterai) untuk menyalakan LED, tampak bahwa LED juga mempunyai nyala yang terang, tetapi lebih redup daripada menggunakan baterai.

\section{SIMPULAN}

Dari hasil dan pembahasan sebelumnya, merupakan hasil penelitian kami dalam hal teknologi energi terbarukan dengan membuat rancang bangun panel surya buatan (efisiensi arus dan voltase mendekati panel surya di pabrikan dan biaya pembuatan sangat murah) hingga tahap fabrikasinya, bertujuan untuk membantu dalam penerimaan akses penerangan (lampu) agar dapat bermanfaat bagi lembaga pendidikan khususnya dan masyarakat pada umumnya, dimana tujuan keberlanjutan kegiatan Perencanaan Program Pengabdian Masyarakat dari ITSNU pasuruan dan LPPM ini adalah membimbing secara intensif terjun secara langsung ke masyarakat (khususnya di sekolah-sekolah Lekok dan Dusun Semongkrong Barat-Tengah yang masih perlu akomodasi saluran listrik murah melalui pembinaan dan pelatihan khusus) hingga dapat mandiri/ hingga panel surya tersebut diproduksi secara massal. 


\section{Saran}

a) Sebagai peserta didik diharapkan mampu membuat inovasi panel surya buatan secara mandiri sehingga dapat memberikan tularan semangat untuk menerapkan hal-hal sederhana menjadi inovasi yang bermanfaat khususnya bagi masyarakat Lekok, Pasuruan.

b) Untuk kebutuhan berkelanjutan, kegiatan ini dapat meringankan beban warga tentang akomodasi listrik khususnya di dusun Semongkrong, Pasinan, Kecamatan Lekok Pasuruan yang belum terjangkau listrik sehingga dapat merasa aman dan tidak dimanfaatkan oleh warga ataupun para remaja untuk melakukan tindakan yang tidak terpuji

\section{UCAPAN TERIMA KASIH}

Tim Penulis mengucapkan terima kasih kepada Segenap Pimpinan Institut Teknologi dan Sains Nahdlatul Ulama (ITSNU) Pasuruan serta Lembaga Penelitian dan Pengabdian Kepada Masyarakat (LPPM) yang telah memberikan Dana Hibah Internal ITSNU Pasuruan, sehingga Kegiatan Pengabdian Masyarakat ini dapat terlaksana dengan baik dan bermanfaat.

\section{DAFTAR PUSTAKA}

5 Desa di Kabupaten Pasuruan Belum Terjangkau Listrik, Ini Sebabnya. (n.d.). Retrieved July 22, 2020, from https://news.detik.com/berita-jawa-timur/d-3592784/5-desa-dikabupaten-pasuruan-belum-terjangkau-listrik-ini-sebabnya

Ali, R. A. M., \& Nayan, N. (1970). Fabrication and analysis of dye-sensitized solar cell using natural dye extracted from dragon fruit. International Journal of Integrated Engineering, $2(3$ SE-Issue on Electrical and Electronic Engineering). https://publisher.uthm.edu.my/ojs/index.php/ijie/article/view/229

Bachtiar, M., Agustina, M., Hariyani, L., \& Nurosyid, F. (2019). Effect of dye variation on DSSC efficiency. Journal of Physics: Conference Series, 1153, 12097. https://doi.org/10.1088/1742-6596/1153/1/012097

Bisakah Panel Surya Jadi Solusi Listrik Padam Seharian? - Ekonomi Bisnis.com. (n.d.). Retrieved May 5, 2020, from https://ekonomi.bisnis.com/read/20190805/44/1132800/bisakah-panel-surya-jadi-solusilistrik-padam-seharian-

Carella, A., Borbone, F., \& Centore, R. (2018). Research Progress on Photosensitizers for DSSC . In Frontiers in Chemistry (Vol. 6, p. 481). https://www.frontiersin.org/article/10.3389/fchem.2018.00481 
Ghann, W., Kang, H., Sheikh, T., Yadav, S., Chavez-Gil, T., Nesbitt, F., \& Uddin, J. (2017). Fabrication, Optimization and Characterization of Natural Dye Sensitized Solar Cell. Scientific Reports, 7(1), 41470. https://doi.org/10.1038/srep41470

Langsung ke Kementerian ESDM, Bupati Irsyad Yusuf Perjuangkan 5 Desa di Lekok Yang Belum Teraliri Listrik PLN | Situs Resmi Pemerintah Kabupaten Pasuruan. (n.d.). Retrieved July 22, 2020, from https://www.pasuruankab.go.id/berita-3837-langsung-kekementerian-esdm-bupati-irsyad-yusuf-perjuangkan-5-desa-di-lekok-yang-belumteraliri-listrik-pln.html

Matahari Sebagai Energi Masa Depan yang Ramah Lingkungan - PLTS Supplier - Surya Energi Indotama. (n.d.). Retrieved May 5, 2020, from https://suryaenergi.com/mataharisebagai-energi-masa-depan-yang-ramah-lingkungan/

Menengok Ladang Panel Surya Terbesar di Indonesia - Kementerian ESDM Republik Indonesia. (n.d.). Retrieved May 5, 2020, from http://ebtke.esdm.go.id/post/2020/03/13/2508/menengok.ladang.panel.surya.terbesar.di.i ndonesia

Pasuruan - Merdeka.com - Ini ikhtiar Bupati Irsyad perjuangkan lima desa agar teraliri listrik. (n.d.). Retrieved July 22, 2020, from https://m.merdeka.com/pasuruan/infopasuruan/ini-ikhtiar-bupati-irsyad-perjuangkan-lima-desa-agar-teraliri-listrik1708097.html

Sawhney, N., Raghav, A., \& Satapathi, S. (2017). Utilization of Naturally Occurring Dyes as Sensitizers in Dye Sensitized Solar Cells. IEEE Journal of Photovoltaics, 7(2), 539-544. https://doi.org/10.1109/JPHOTOV.2016.2639343

Shalini, S., Balasundaraprabhu, R., Kumar, T. S., Prabavathy, N., Senthilarasu, S., \& Prasanna, S. (2016). Status and outlook of sensitizers/dyes used in dye sensitized solar cells (DSSC): a review. International Journal of Energy Research, 40(10), 1303-1320. https://doi.org/10.1002/er.3538

Torchani, A., Saadaoui, S., Gharbi, R., \& Fathallah, M. (2015). Sensitized solar cells based on natural dyes. Current Applied Physics, 15(3), 307-312. https://doi.org/https://doi.org/10.1016/j.cap.2015.01.003

Tulandi, D. (2019). PKM PENINGKATAN KOMPETENSI GURU FISIKA SMA DALAM MENGEMBANGKAN KEMAMPUAN PEMBUATAN ALAT PRAKTIKUM. Edupreneur: Jurnal Pengabdian Kepada Masyarakat Bidang Kewirausahaan, 2. https://doi.org/10.36412/edupreneur.v2i1.874

Zin, N. S., Blakers, A., Franklin, E., \& Everett, V. (2008). Design, characterization and fabrication of silicon solar cells for $\gg 50 \%$ efficient 6-junction tandem solar cells. 2008 33rd IEEE Photovoltaic Specialists Conference, 1-4. https://doi.org/10.1109/PVSC.2008.4922451 